Article

\title{
Effect of Corn Dried Distiller Grains with Solubles (DDGS) in Dairy Cow Diets on Manure Bioenergy Production Potential
}

\author{
Daniel I. Massé *, Guillaume Jarret, Chaouki Benchaar and Noori M. Cata Saady \\ Agriculture and Agri-Food Canada, 2000 College Street, Sherbrooke, Quebec, J1M 0C8, Canada; \\ E-Mails: Guillaume.Jarret@agr.gc.ca (G.J.); Chaouki.Benchaar@agr.gc.ca (C.B.); \\ Noori.Saady@agr.gc.ca (N.M.C.S.)
}

* Author to whom correspondence should be addressed; E-Mail: Daniel.Masse@agr.gc.ca; Tel.: +1-819-780-7128; Fax: +1-819-5564-5507.

Received: 4 December 2013; in revised form: 22 January 2014 / Accepted: 26 February 2014 / Published: 5 March 2014

Simple Summary: Among the measures proposed to reduce environmental pollution from the livestock sector, animal nutrition has a strong potential to reduce enteric and manure storages methane emissions. Changes in diet composition also affect the bioenergy potential of dairy manures. Corn dried distillers grains with solubles (DDGS), which are rich in fat, can be included in animal diets to reduce enteric methane $\left(\mathrm{CH}_{4}\right)$ emissions, while increasing the bioenergy potential of the animal manure during anaerobic digestion. The inclusion of $30 \%$ DDGS in the cow diet caused a significant increase of $14 \%$ in daily bioenergy production ( ${ }_{\mathrm{N}} \mathrm{L}$ methane day $\left.{ }^{-1} \cdot \operatorname{cow}^{-1}\right)$.

\begin{abstract}
The main objective of this study was to obtain scientifically sound data on the bioenergy potential of dairy manures from cows fed different levels of corn dried distillers grains with solubles (DDGS). Three diets differing in corn DDGS content were formulated: $0 \%$ corn DDGS (DDGS0; control diet), 10\% corn DDGS (DDGS10) and 30\% corn DDGS (DDGS30). Bioenergy production was determined in psychrophilic $\left(25 \pm 1^{\circ} \mathrm{C}\right)$ sequencing batch reactors (SBRs) fed $3 \mathrm{~g} \mathrm{COD} \mathrm{L}{ }^{-1} \cdot$ day $^{-1}$ during a two-week feeding period followed by a two-week react period. Compared to the control diet, adding DDGS10 and DDGS30 to the dairy cow diet increased the daily amount of fat excreted in slurry by $29 \%$ and $70 \%$, respectively. The addition of DDGS30 increased the cows' daily production of fresh feces and slurry by $15 \%$ and $11 \%$, respectively. Furthermore, the incorporation of DDGS30 in the diet increased the daily amounts of dry matter (DM), volatile solids (VS), neutral detergent fiber (NDF), acid detergent fiber (ADF) and hemicellulose by $18 \%, 18 \%, 30 \%$,
\end{abstract}


$15 \%$ and $53 \%$, respectively, compared to the control diet. While the addition of DDGS did not significantly affect the specific $\mathrm{CH}_{4}$ production per $\mathrm{kg}$ VS compared to the control diet, DDGS30 increased the per cow daily $\mathrm{CH}_{4}$ production by $14 \%$ compared to the control diet.

Keywords: corn DDGS; dairy; manure; methane; bioenergy; psychrophilic

\section{Introduction}

Manure produced by livestock operations contributes to greenhouse gas (GHG) emissions. In Canada, GHG emissions produced by the livestock sector represent about $8 \%$ of total national GHG emissions, and manure accounts for about $12 \%$ of agricultural emissions [1]. Methane $\left(\mathrm{CH}_{4}\right)$, one of the principal agricultural GHGs, is produced by enteric fermentation in ruminant animals [2] and by anaerobic fermentation of manure in livestock buildings and manure storage facilities $[3,4]$. The level of $\mathrm{CH}_{4}$ emissions during manure storage is affected by environmental factors such as storage temperature [5,6], storage duration [7], manure composition, and bedding content [7-9]. Environmental legislation and public concern about the environmental footprint of livestock production operations have increased the pressure on producers to take measures to reduce atmospheric and environmental pollution. Among all the measures proposed to reduce environmental pollution from the livestock sector, animal nutrition has a strong potential to reduce enteric and manure storages $\mathrm{CH}_{4}$ emissions. Changes in diet composition may also affect the bioenergy potential of dairy manures. The recent increase in biofuel by-products, such as corn dried distillers grains with solubles (DDGS), which are rich in fat, may be a good candidate by-product to include in animal diets with a view to reducing enteric $\mathrm{CH}_{4}$ emissions [10]. The addition of fat to a diet reduces or eliminates protozoa as well as methanogenic bacteria in the rumen, resulting in decreased $\mathrm{CH}_{4}$ emissions and a shift in the hydrogen sink through bio-hydrogenation via propionate production $[11,12]$. DDGS by-products are also rich in fiber complexes with nutrients (such as protein and carbohydrates) that are partially digested in the rumen and gut of the animal. This could increase the amounts of nutrients available for microbial fermentation in the slurry, thus potentially facilitating a compensatory increase of $\mathrm{CH}_{4}$ production as reported in the study of Külling et al. [13]. Jarret et al. [14] showed that the inclusion of wheat DDGS in pig diets could modify manure quantity and characteristics and thus alter the GHG budget of manure during anaerobic digestion by increasing biogas production. Green energy recovery via biogas production combined with on-farm power/heat generation seems the most logical approach for reducing fossil fuel use at the farm level and the carbon footprint of dairy products. This study used an integrated approach to assess manure-based bioenergy recovery potential in relation to dairy cow diets compositions. Within this context, the objective of this study was to investigate the effect DDGS level in the dairy cow diet on manure bioenergy production. 


\section{Materials and Methods}

\subsection{Experimental Design}

As part of an integrated research project to assess the carbon footprint of milk products in Canada, two experiments were conducted: (1) An animal experiment to evaluate the impact of the level of corn DDGS inclusion as a fat source in Holstein cow's diets on enteric $\mathrm{CH}_{4}$ emissions and on milk yield and composition; (2) A bioenergy potential assessment experiment.

In the animal experiment (used Latin square design), diets containing four different levels of steam-flaked corn DDGS (dry matter-based): 0\% - DDGS0, considered as the control diet; 10\% DDGS10; 20\% - DDGS20; and 30\% - DDGS30 was fed to 16 lactating Holstein cows (645 $\pm 49 \mathrm{~kg}$ ) were fed (i.e., 4 diets $\times 4$ cows involved for each diet $=16$ cows in each experimental period); four testing periods (duration of each testing period was 4 months) were conducted as per the Latin square design. For the assessment of the effect of diet composition on manure physico-chemical characteristics, urine and feces were collected daily from the 16 cows involved in the 4 diet testing periods.

The collection of feces and urine has been described elsewhere [15]. Briefly, Cows were fitted with harnesses and tubes allowing the collection of feces and urine separately. Feces were weighed and mixed daily, and a representative sample $(2 \%)$ was collected, stored at $-20{ }^{\circ} \mathrm{C}$, and subsequently thawed, freeze dried, and ground to pass a 1-mm screen using a Wiley mill for later analysis of DM, VS, total N, NDF, ADF and other parameters. Total urine was collected daily into reinforced plastic containers. The composition of the diets is presented in Table 1 [15].

In the bioenergy potential assessment experiment, the manure (cow feces and urine) produced from the DDGS0, DDGS10, DDGS30 diets during the first testing period only has been used as substrate for anaerobic digestion. Therefore, for the bioenergy potential assessment experiment 12 cows were involved ( 4 cows for each diet $\times 3$ diets (DDGS0, DDGS10, DDGS30)). The manure slurries were stored in 200 -L containers maintained at $4{ }^{\circ} \mathrm{C}$. At the end of the collection period, the slurries were homogenized using a portable mechanical mixer and subsamples were taken for analysis.

Table 1. Ingredients and composition of the three diets tested: $0,10 \%$ and $30 \%$ dried distillers grains with solubles (DDGS0, DDGS10 and DDGS30), and volume and composition of dairy cow slurry $\left(\mathrm{kg} \cdot \mathrm{day}^{-1} \cdot \mathrm{cow}^{-1}\right)$ as a function of feeding strategy.

\begin{tabular}{|c|c|c|c|c|c|}
\hline & DDGSO & DDGS10 & DDGS30 & SEM $^{\alpha}$ & $p$-Value \\
\hline \multicolumn{6}{|l|}{ Ingredients, \% DM ${ }^{\beta}$} \\
\hline Alfalfa silage & 22.9 & 22.9 & 22.9 & & \\
\hline Corn silage & 33.8 & 33.8 & 33.8 & & \\
\hline Timothy hay & 3.4 & 3.4 & 3.4 & & \\
\hline Steam-flaked corn & 16.7 & 11.0 & 0.0 & & \\
\hline Soybean meal & 13.2 & 8.8 & 0.0 & & \\
\hline $\begin{array}{l}\text { Corn dried distillers grains with } \\
\text { Solubles }\end{array}$ & 0.0 & 10.1 & 30.0 & & \\
\hline Beet pulp, dehydrated & 7.6 & 7.6 & 7.5 & & \\
\hline Calcium carbonate & 0.7 & 0.7 & 0.8 & & \\
\hline Mineral and vitamin supplement & 1.6 & 1.6 & 1.5 & & \\
\hline
\end{tabular}


Table 1. Cont.

\begin{tabular}{|c|c|c|c|c|c|}
\hline & DDGS0 & DDGS10 & DDGS30 & SEM $^{\alpha}$ & $p$-Value \\
\hline \multicolumn{6}{|l|}{ Composition, \% DM } \\
\hline Organic matter & 93.0 & 92.9 & 92.5 & & \\
\hline Crude protein & 16.2 & 16.4 & 16.8 & & \\
\hline Acid detergent fiber (ADF) & 21.8 & 21.8 & 23.3 & & \\
\hline Starch & 19.0 & 15.8 & 11.2 & & \\
\hline Crude fat & 3.99 & 4.98 & 7.16 & & \\
\hline \multicolumn{6}{|l|}{ 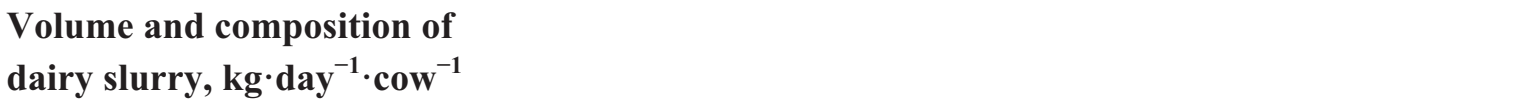 } \\
\hline Slurry & $76.1^{\mathrm{b}}$ & $80.2^{\mathrm{ab}}$ & $84.4^{\mathrm{a}}$ & 2.55 & $<0.01$ \\
\hline Feces & $51.9^{\mathrm{b}}$ & $55.2^{\mathrm{b}}$ & $59.8^{\mathrm{a}}$ & 2.33 & $<0.01$ \\
\hline Urine & $24.3^{\mathrm{a}}$ & $25.0^{\mathrm{a}}$ & $24.6^{\mathrm{a}}$ & 0.34 & 0.71 \\
\hline Dry matter ${ }^{\beta}$ & $6.85^{\mathrm{b}}$ & $7.28^{\mathrm{b}}$ & $8.06^{\mathrm{a}}$ & 0.228 & $<0.01$ \\
\hline Volatile solids & $5.98^{\mathrm{b}}$ & $6.39^{\mathrm{b}}$ & $7.05^{\mathrm{a}}$ & 0.203 & $<0.01$ \\
\hline Nitrogen & $0.395^{\mathrm{b}}$ & $0.406^{\mathrm{ab}}$ & $0.426^{\mathrm{a}}$ & 0.0125 & 0.05 \\
\hline Fat & $0.433^{\mathrm{c}}$ & $0.557^{\mathrm{b}}$ & $0.737^{\mathrm{a}}$ & 0.0231 & $<0.01$ \\
\hline Neutral detergent fiber (NDF) & $3.30^{\mathrm{b}}$ & $3.55^{\mathrm{b}}$ & $4.30^{\mathrm{a}}$ & 0.131 & $<0.01$ \\
\hline $\mathrm{ADF}$ & $2.00^{\mathrm{b}}$ & $2.09^{b}$ & $2.30^{\mathrm{a}}$ & 0.081 & $<0.01$ \\
\hline Hemicellulose & $1.31^{\mathrm{b}}$ & $1.46^{\mathrm{b}}$ & $2.00^{\mathrm{a}}$ & 0.067 & $<0.01$ \\
\hline
\end{tabular}

${ }^{\alpha}$ SEM: Standard Error of the Mean; $p$-Value for diet effect. Means on the same line with different superscripts $\left({ }^{(a, b, c}\right)$ differ significantly $(p<0.05) ;{ }^{\beta}$ DM: dry matter; NDF; ADF; hemicellulose. The number of samples for the compositional analysis of the dairy slurry was 36 from all testing periods.

\subsection{Incubation Set-Up}

Bioenergy production measurements were performed on laboratory-scale anaerobic sequencing batch reactors (SBRs) operated under psychrophilic conditions. Six 54-L SBRs located in a controlled-environmental chamber operated at $25 \pm 1{ }^{\circ} \mathrm{C}$ were used over a 4 -month period. The details of the SBR are shown in Figure 1. At the beginning of the experiment, each SBR contained $20 \mathrm{~kg}$ of psychrophilic anaerobic inoculum obtained from a semi-commercial scale SBR operated at a temperature of $25^{\circ} \mathrm{C}$. The physico-chemical characteristics of the inoculum are given in Table 2 . The semi-industrial digester was located at the Dairy and Swine Research and Development Centre, Sherbrooke, Quebec-Canada. The hydraulic retention time (HRT) was $30 \mathrm{~d}$; the SBRs were operated with feed and react periods of 2 weeks each. The first 3-month period of operation was used to ensure that a steady state was reached and the last month, to determine daily biogas production. The organic loading rate (OLR) was equivalent to $3 \mathrm{~g}$ of $\mathrm{COD} \mathrm{L}^{-1}$. day ${ }^{-1}$ during the feeding period. The amounts of slurry fed into the SBRs were $6.00 \mathrm{~kg}$ for the DDGS0 diet; $6.72 \mathrm{~kg}$ for the DDGS10 diet; and $6.00 \mathrm{~kg}$ for the DDGS30 diet. The contents of the SBRs were mixed twice a week for $5 \mathrm{~min}$. A 100-mL sample of mixed liquor was collected after 5 min of mixing and analyzed to assess the level of degradation of the organic matter. Daily biogas production from slurry corresponding to each diet treatment (2 SBRs/dietary treatments) was monitored. 
Figure 1. Schematic diagram of the sequence batch reactor.

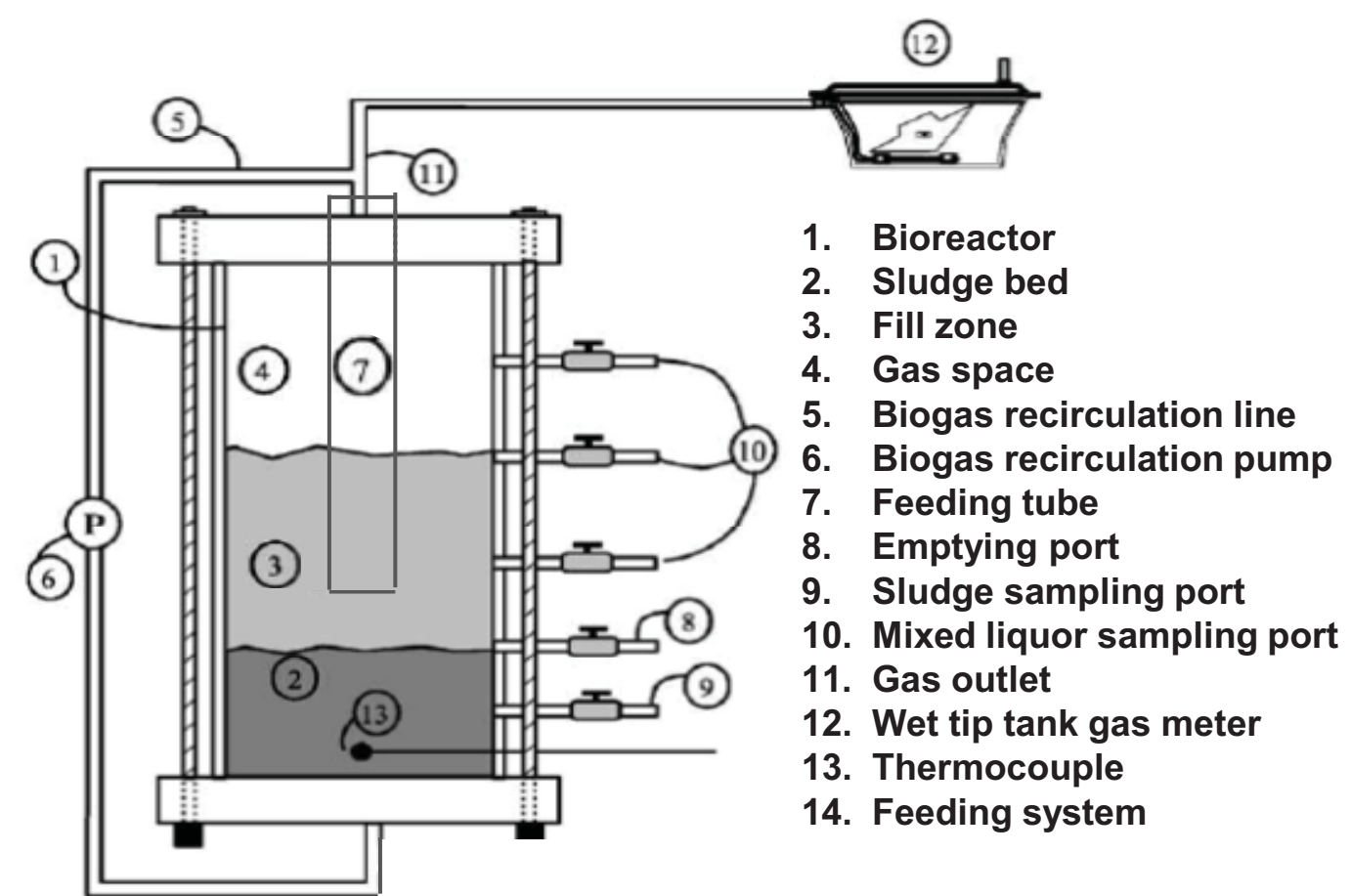

Table 2. The physico-chemical characteristics of the inoculum.

\begin{tabular}{lc}
\hline Parameter & Concentration \\
\hline Volatile fatty acids (VFAs) & $48.1 \mathrm{mg} \cdot \mathrm{L}^{-1}$ \\
pH & 7.48 \\
Dry matter (DM) & $3.4 \%$ \\
Volatile solids (VS) & $2.4 \%$ \\
Fixed solids (FS) & $1.0 \%$ \\
Soluble chemical oxygen demand (SCOD) & $6.8 \mathrm{~g} \cdot \mathrm{L}^{-1}$ \\
Total chemical oxygen demand (TCOD) & $37.3 \mathrm{~g} \cdot \mathrm{L}^{-1}$ \\
N-ammonia $\left(\mathrm{N}-\mathrm{NH}_{3}\right)$ & $1.8 \mathrm{~g} \cdot \mathrm{L}^{-1}$ \\
Total Kjeldahl nitrogen (TKN) & $2.8 \mathrm{~g} \cdot \mathrm{L}^{-1}$ \\
\hline
\end{tabular}

\subsection{Monitoring Gaseous Emissions}

All storage structures and SBRs were closed hermetically in order to capture and measure daily biogas production with wet tip gas meters. Biogas samples were collected once a week using a plastic syringe and analyzed to determine the proportion (in \%) of $\mathrm{CH}_{4}$ in the biogas with Hach Carle 400 AGC gas chromatograph (Model 04131-C, Hach, Loveland, CO, USA) configured for the application 131-C. The application uses a column (1/8 inches) composed of $1.8 \mathrm{~m}$ (805 porapak $\mathrm{N}+205$ Porapak Q), $2.1 \mathrm{~m}(80 \%$ molecular sieve $13 \mathrm{X}+20 \%$ molecular Sieve $5 \mathrm{~A})$, and $1.8 \mathrm{~m}(80 \% \mathrm{OV}-101$ on chromosorb WHP). The column and thermal conductivity detector were operated at $85{ }^{\circ} \mathrm{C}$ with a helium gas flow rate of $30 \mathrm{~mL} \cdot \mathrm{min}^{-1}$ [7]. Calibration was performed weekly with a standard gas $\left(27.3 \% \mathrm{CO}_{2}, 1.01 \% \mathrm{~N}_{2}, 71.69 \% \mathrm{CH}_{4}, 0.53 \% \mathrm{H}_{2} \mathrm{~S}\right)$.

Methane $\left(\mathrm{CH}_{4}\right)$ production is reported in normalized litres $\left({ }_{\mathrm{N}} \mathrm{CH}_{4}\right)$, i.e., the $\mathrm{CH}_{4}$ volume produced was corrected to standard temperature and pressure (STP) $\left(273{ }^{\circ} \mathrm{K} ; 1 \mathrm{~atm}\right)$ using Equation (1). 


$$
V_{C H_{4 S T P}}=\eta V_{m} \frac{T_{s} \cdot P_{m}}{T_{m} \cdot P_{s}}
$$

where $V_{m}$ is the measured volume of biogas, $\eta$ is the percentage of $\mathrm{CH}_{4}$ in biogas, $T m$ and $P_{m}$ which are the actual temperature and atmospheric pressure at the time of measurement, and $T_{s}$ and $P_{s}$ are the standard temperature and pressure. $V_{C_{4 S T P}}$ is the volume of methane at the standard temperature and atmospheric pressure. The yield of biogas and $\mathrm{CH}_{4}$ were expressed in ${ }_{\mathrm{N}} \mathrm{CH}_{4} \cdot \mathrm{kg}^{-1} \mathrm{VS}$ and in ${ }_{\mathrm{N}} \mathrm{CH}_{4}$ day $^{-1} \cdot \operatorname{cow}^{-1}$.

\subsection{Chemical Analyses}

Slurries were sampled and analyzed prior each feeding over the 4-month trial and the bioreactor mixed liquors were sampled twice a week during the last $30 \mathrm{~d}$ (HRT) and analyzed for $\mathrm{pH}, \mathrm{DM}$, VS, FS, Soluble and total chemical oxygen demand (SCOD and TCOD, respectively) [16], phosphorus (P), $\mathrm{N}-\mathrm{NH}_{3}, \mathrm{TKN}$ and VFAs. The VFAs (acetic, propionic, butyric, isobutyric, isovaleric) were analyzed using Perkin Elmer gas chromatograph (GC) model 8310 (Perkin Elmer, Norwalk, CT, USA) fitted with FID and, equipped with a J\&W Scientific DB-FFAP high resolution column $(30 \mathrm{~m} \times 0.53 \mathrm{~mm} \times$ $1.00 \mu \mathrm{m}$; Chromatographic Specialties Inc, Ontario) [7]. The SCOD and TCOD were determined by the closed reflux colorimetric method [16]. The SCOD was measured on the supernatant of a centrifuged sample. The DM content was determined by drying a $10 \mathrm{~g}$ subsample for $24 \mathrm{~h}$ at $105^{\circ} \mathrm{C}$. Dried solids were then incinerated for $2 \mathrm{~h}$ at $550{ }^{\circ} \mathrm{C}$ for volatile content measurement. The P and TKN were analyzed on a subsample digested at $420{ }^{\circ} \mathrm{C}$ with selenious acid. Concentrations of TKN and

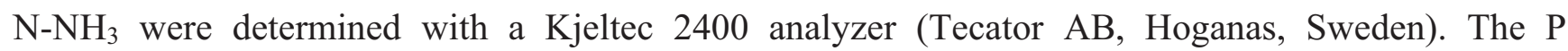
concentration was measured with a Lambda 35 spectrometer (Perkin Elmer, Shelton, CT, USA). Cell wall fractions (neutral detergent fiber $[\mathrm{NDF}$ ] and acid detergent fiber [ADF]) in manure were determined according to the methods of Van Soest and Wine [17] by using a sequential procedure with amylolytic (thermamyl $120 \mathrm{~L}$ ) treatment.

\subsection{Calculations and Statistical Analysis}

Data on the volume and composition of the three slurries from the study involving 12 dairy cows over the diet testing periods [15] were analyzed with diet as the main effect in a $4 \times 4$ Latin Square design using the SAS MIXED procedure (SAS release 9.1; SAS Institute Inc., Cary, NC, USA). The composition of the slurries at the beginning and end of the bioenergy trial were analyzed by ANOVA as a completely randomized design with dietary treatment as the main effect, using the SAS MIXED procedure (SAS release 9.1; SAS Institute Inc., Cary, NC, USA).

$\mathrm{CH}_{4}$ production results from the SBRs were also analyzed by ANOVA using the SAS MIXED procedure with diet as the main effect. Multiple means testing was performed using the Tukey test.

The bioenergy production potential was determined by the following equations:

Daily $\mathrm{CH}_{4}$ production:

$$
V \mathrm{CH}_{4}(n)=\mathrm{V}(n) x \mathrm{CH}_{4}(n)
$$


Cumulative $\mathrm{CH}_{4}$ over the bioenergy production trial:

$$
\mathrm{VCH}_{4}=\mathrm{\Sigma} \mathrm{VCH}_{4}(n)
$$

Cumulative specific $\mathrm{CH}_{4}$ over bioenergy production trial:

$$
\text { Specific } \mathrm{V} \mathrm{CH}_{4}=\mathrm{V} \mathrm{CH}_{4} \text { cumulated / MVS added }
$$

where $n$ is the day the measurement is recorded, $V(n)$ is the volume (L) of biogas and $\mathrm{CH}_{4}(n)$ is the $\mathrm{CH}_{4}$ content in biogas on that specific day, and $M V S$ is the total mass of volatile solids fed to the bioreactors $(\mathrm{kg})$. Cumulative $\mathrm{V} \mathrm{CH}_{4}$ was obtained by summing the daily $\mathrm{CH}_{4}$ production over the one-month trial for bioenergy production.

To express the bioenergy production in ${ }_{N} \mathrm{~L} \mathrm{CH} \mathrm{CH}_{4}$ day ${ }^{-1} \cdot \mathrm{cow}^{-1}$, the cumulative $\mathrm{CH}_{4}$ emissions expressed in ${ }_{\mathrm{N}} \mathrm{CH}_{4} \mathrm{~kg}^{-1}$ of VS were divided by the number of days of the trial and multiplied by the amount of VS excreted daily per cow for each dietary treatment.

\section{Results and Discussion}

\subsection{Effect of Adding Different Levels of Corn DDGS to the Dairy Cow Diet on Slurry Characteristics}

The inclusion of corn DDGS had no effect on urine production but dairy cows fed DDGS30 showed a significant increase in the amount of fresh feces and slurry excreted per day, specifically $15 \%$ $(p<0.01)$ and $11 \%(p<0.01)$, respectively, compared to the control diet. The different levels of corn DDGS included in the cow diet had a significant influence $(p<0.05)$ on some of the physico-chemical characteristics of manure slurry (Table 1). The inclusion of $10 \%$ corn DDGS was associated with a significant increase of $29 \%(p<0.01)$ in the daily amount of fat excreted in slurry compared to the control diet. The addition of $30 \%$ corn DDGS to the diet caused the following significant increases relative to the control diet: $18 \%$ increase in the daily amount of $\mathrm{DM}(p<0.01) ; 18 \%$ increase in VS $(p<0.01) ; 70 \%$ increase in fat $(p<0.01) ; 30 \%$ increase in NDF $(p<0.01) ; 15 \%$ increase in ADF $(p<0.01)$; and $53 \%$ increase in hemicellulose $(p<0.01)$.

There are three possible explanations for the increase in the daily amount of slurry: (i) an increase in DM intake tends to decrease nutrient digestion efficiency because feed passes through the digestive system faster; (ii) an increase in water intake moves digestate faster [18]; and (iii) a high degree of lignification of the fiber in the corn DDGS would make it largely inaccessible for degradation by microorganisms present in the digestive tract [19]. Weiss and Wyatt [20] reported that manure output usually increases as the concentration of dietary fiber (NDF) increases. This occurs because NDF is generally less digestible than other nutrients. On average, a $1 \%$ unit increase in NDF concentration increases manure output by 0.23 to $0.45 \mathrm{~kg} \cdot \mathrm{day}^{-1}$. A decrease in fiber digestibility could also explain the increase in the daily amount of DM, VS, NDF, ADF and hemicellulose excreted in connection with the diet including 30\% corn DDGS.

\subsection{Effects of Diets on Bioenergy Production}

The initial composition of the slurries fed into the SBRs at the beginning of the 4-month trial showed that the slurries resulting from corn DDGS diets differed significantly from the control with respect to certain physico-chemical characteristics, specifically DM, TVFA, pH, TCOD, SCOD, TKN 
and $\mathrm{NH}_{3}$ (Table 3). In the case of the slurry from the DDGS10 diet, the TVFA and SCOD values were significantly higher (18\% and $9 \%$, respectively) and the $\mathrm{pH}, \mathrm{TKN}$ and $\mathrm{NH}_{3}$ contents were significantly lower (1\%, $4 \%$ and $5 \%$, respectively) than for the control diet. The DM, TVFA, SCOD, TKN and $\mathrm{NH}_{3}$ in the slurry from the DDGS30 diet were significantly lower $(6 \%, 22 \%, 7 \%, 4 \%$ and $5 \%$, respectively) and TCOD was significantly higher (9\%) than for the control diet (Table 3 ).

Table 3. Initial and final composition of slurry and $\mathrm{CH}_{4}$ production during the bioenergy production trial as a function of feeding strategy (inclusion of $0,10 \%, 30 \%$ corn dried distillers grains with solubles - DDGS0, DDGS10 and DDGS30)

\begin{tabular}{|c|c|c|c|c|c|}
\hline & DDGSO & DDGS10 & DDGS30 & SEM $^{\alpha}$ & $p$-Value \\
\hline \multicolumn{6}{|l|}{ Initial composition, \% DM } \\
\hline Dry matter (DM, \%) & $6.18^{\mathrm{a}}$ & $6.13^{\mathrm{a}}$ & $5.84^{\mathrm{b}}$ & 0.04 & $<0.05$ \\
\hline Volatile solids (VS) & $74^{\mathrm{a}}$ & $74^{\mathrm{a}}$ & $75^{\mathrm{a}}$ & 0.20 & 0.12 \\
\hline Fixed solids (FS) & $26^{\mathrm{a}}$ & $26^{\mathrm{a}}$ & $25^{\mathrm{a}}$ & 0.20 & 0.12 \\
\hline Total volatile fatty acids (TVFA) & $5.28^{\mathrm{b}}$ & $6.21^{\mathrm{a}}$ & $4.12^{\mathrm{c}}$ & 0.04 & $<0.01$ \\
\hline $\mathrm{pH}$ & $7.40^{\mathrm{a}}$ & $7.32^{\mathrm{b}}$ & $7.36^{\mathrm{ab}}$ & 0.008 & $<0.05$ \\
\hline $\begin{array}{l}\text { Total chemical oxygen demand } \\
\text { (TCOD) }\end{array}$ & $109^{\mathrm{b}}$ & $109^{\mathrm{b}}$ & $119^{\mathrm{a}}$ & 1.75 & $<0.05$ \\
\hline Soluble COD & $26.8^{\mathrm{b}}$ & $29.2^{\mathrm{a}}$ & $24.8^{\mathrm{c}}$ & 0.28 & $<0.01$ \\
\hline Total Kjedahl nitrogen (TKN) & $7.57^{\mathrm{a}}$ & $7.31^{\mathrm{b}}$ & $7.20^{\mathrm{b}}$ & 0.03 & $<0.01$ \\
\hline Ammonia $\left(\mathrm{NH}_{3}\right)$ & $5.28^{\mathrm{a}}$ & $5.01^{\mathrm{b}}$ & $4.98^{\mathrm{b}}$ & 0.03 & $<0.01$ \\
\hline \multicolumn{6}{|l|}{ Final composition, \% DM } \\
\hline $\mathrm{DM}(\%)$ & $5.41^{\mathrm{a}}$ & $5.40^{\mathrm{a}}$ & $4.79^{\mathrm{a}}$ & 0.15 & 0.09 \\
\hline VS & $70^{\mathrm{a}}$ & $71^{\mathrm{a}}$ & $69^{\mathrm{a}}$ & 0.71 & 0.20 \\
\hline FS & $30^{\mathrm{a}}$ & $29^{\mathrm{a}}$ & $31^{\mathrm{a}}$ & 0.71 & 0.20 \\
\hline TVFA & $0.29^{\mathrm{a}}$ & $0.36^{\mathrm{a}}$ & $0.40^{\mathrm{a}}$ & 0.03 & 0.14 \\
\hline $\mathrm{pH}$ & $7.62^{\mathrm{a}}$ & $7.59^{\mathrm{a}}$ & $7.59^{\mathrm{a}}$ & 0.01 & 0.28 \\
\hline TCOD & $106^{\mathrm{ab}}$ & $108^{\mathrm{a}}$ & $103^{\mathrm{b}}$ & 0.48 & $<0.05$ \\
\hline SCOD & $23.5^{\mathrm{a}}$ & $22.7^{\mathrm{a}}$ & $19.2^{\mathrm{b}}$ & 0.47 & $<0.05$ \\
\hline TKN & $8.70^{\mathrm{a}}$ & $8.30^{\mathrm{a}}$ & $8.32^{\mathrm{a}}$ & 0.52 & 0.84 \\
\hline $\mathrm{NH}_{3}$ & $6.60^{\mathrm{a}}$ & $6.12^{\mathrm{a}}$ & $6.53^{\mathrm{a}}$ & 0.22 & 0.38 \\
\hline \multicolumn{6}{|l|}{ Bioenergy production } \\
\hline${ }_{\mathrm{N}} \mathrm{C} \mathrm{CH}_{4} \mathrm{~kg}^{-1} \mathrm{VS}$ & $255.8^{\mathrm{a}}$ & $265.0^{\mathrm{a}}$ & $252.9^{\mathrm{a}}$ & 1.58 & 0.34 \\
\hline${ }_{N} \mathrm{~L} \mathrm{CH}_{4}$ day $^{-1} \cdot \mathrm{cow}^{-1}$ & $947.5^{\mathrm{b}}$ & $1054^{\mathrm{ab}}$ & $1084^{\mathrm{a}}$ & 13.23 & $<0.05$ \\
\hline
\end{tabular}

${ }^{\alpha}$ SEM: Standard Error of the Mean; P-Value for diet effect. Means on the same line with different superscript letters $\left({ }^{\mathrm{a}, \mathrm{b}, \mathrm{c}}\right)$ differ significantly $(p<0.05)$. The data in the table is the average of 8 samples for each diet.

The final composition indicated that residual TVFA were nearly zero for all dietary treatments (Table 3) and that SCOD was significantly lower (18\%) in the slurry from the DDGS30 diet than in the control diet.

Bioenergy production expressed in ${ }_{\mathrm{N}} \mathrm{CH}_{4} \cdot \mathrm{kg}^{-1} \mathrm{VS}$ was not affected significantly by diet. However, when the increase in the volume of manure excreted daily per cow with the addition of corn DGGS is considered, it can be seen that daily $\mathrm{CH}_{4}$ production per cow increased significantly in the 
slurry from the DDGS30 diet (14\%) compared to the control diet (Table 3). These results can be explained by the fact that the amount of slurry excreted daily per cow was significantly higher for the DDGS30 diet than for the other two diets. Similar findings have been reported for incorporating different fiber contents in pig diets [14] and for incorporating fat in cattle diets [21]. Based on what is reported in the literature, the higher bioenergy production from the DDGS30 treatment could be expected because the organic content of this slurry was greater than that of the slurries from the other two diets. It appears that the increase in bioenergy production is not attributable solely to the amount of nutrients excreted and that the type of nutrients had an effect. This study shows that the inclusion of $30 \%$ DDGS caused a significant increase in the amount of fats, NDF, ADF and hemicellulose (0.304, $1.0,0.30$, and $0.69 \mathrm{~kg} \mathrm{~d}^{-1} \cdot \mathrm{cow}^{-1}$, respectively (Table 1)) excreted in the slurry. Fibers such as lignin are known to build complexes with cellulose and hemicellulose, thus creating a physical barrier making it difficult for microbial enzymes to break down the organic compounds in short time. However, $80 \%$ degradation of carbohydrate fibers requires around 30 days [22] which has been provided by the HRT used in this study. Notice that the theoretical methane potential per gram of VS is significantly greater for fat compared to proteins and carbohydrate $\left(1014,496\right.$, and $415{ }_{\mathrm{N}} \mathrm{C} \mathrm{CH}_{4} \cdot \mathrm{kg}^{-1}$ VS, respectively) [22].

\section{Conclusion}

Although the inclusion of corn DDGS had no effect on urine production, dairy cows fed DDGS30 showed a significant increase of $11 \%$ and $15 \%$ in the amount of fresh slurry and fresh feces excreted per day, respectively. The DDGS10 treatment caused a significant increase (29\%) in the daily amount of fat, and the DDGS30 treatment increased the daily DM, volatile solids (VS), fat, neutral detergent fiber (NDF), acid detergent fiber (ADF) and hemicellulose contents by $18 \%, 18 \%, 70 \%, 30 \%, 15 \%$ and $53 \%$, respectively, compared to the control diet. The bioenergy production trial showed that the inclusion of corn DDGS30 caused a significant increase of $14 \%$ in daily bioenergy production ${ }_{\mathrm{N}} \mathrm{L} \mathrm{CH}_{4}$ day $^{-1} \cdot \operatorname{cow}^{-1}$ ). These data will be used to carry out a detailed and comprehensive life cycle analysis to assess the level of reduction in carbon footprint of Canadian dairy products via the adoption of anaerobic digestion and inclusion of DDGS in dairy diets.

\section{Acknowledgements}

This project has been financially supported through contributions from Agriculture and Agri-Food Canada, the Canadian Dairy Commission and Dairy Farmers of Canada under the Dairy Research Cluster Program.

\section{Author Contributions}

Conceived and design the experiments: DM; obtained the financial support: DM; performed the bioenergy experiments: GJ and DM; analyzed the data: DM, GJ, NCS; contributed reagents/materials/ analysis tools: DM; conceived the animal experiment: CB; wrote the paper: DM, GJ, NCS, CB. 


\section{Conflicts of Interest}

The authors declare no conflict of interest.

\section{References}

1. Fournel, S.; Pelletier, F.; Godbout, S.; Lagacé, R.; Feddes, J. Greenhouse gas emissions from three cage layer housing systems. Animals 2012, 2, 1-15.

2. Kebreab, E.; Clark, K.; Wagner-Riddle, C.; France, J. Methane and nitrous oxide emissions from Canadian animal agriculture: A review. Can. J. Anim. Sci. 2006, 86, 135-158.

3. Husted, S. Seasonal variation in methane emissions from stored slurry and solid manures. J. Environ. Qual. 1994, 23, 585-592.

4. Massé, D.I.; Masse, L.; Claveau, S.; Benchaar, C.; Tremblay, F.; Thomas, O. Methane emissions from Manure storages. Trans. ASAE 2008, 51, 1775-1781.

5. Khan, R.Z.; Müller, C.; Sommer, S.G. Micrometeorological mass balance technique for measuring $\mathrm{CH}_{4}$ emissions from stored cattle slurry. Biol. Fert. Soils 1997, 24, 442-444.

6. Park, K.H.; Thompson, A.G.; Marinier, M.; Clark, K.; Wagner-Riddle, C. Greenhouse gas emissions from stored liquid swine manure in a cold climate. Atmos. Environ. 2006, 40, 618-627.

7. Massé, D.I.; Masse, L.; Croteau, F. The effect of temperature fluctuations on psychrophilic anaerobic sequencing batch reactors treating swine manure. Bioresour. Technol. 2003, 89, 57-62.

8. Chen, T.H.; Day, D.L.; Steinberg, M.P. Methane production from fresh versus dry dairy manure. Biol. Waste 1998, 24, 297-306.

9. Dinuccio, E.; Berg, W.; Balsari, P. Gaseous emissions from the storage of untreated slurries and fractions obtained after mechanical separation. Atmos. Environ. 2008, 42, 2448-2459.

10. McGinn, S.M.; Chung, Y.H.; Beauchemin, K.A.; Iwaasa, A.D.; Grainger, C. Use of corn distiller's dried grains to reduce enteric methane loss from beef cattle. Can. J. Anim. Sci. 2009, 89, 409-413.

11. Lovett, D.; Lovell, S.; Stack, L.; Callan, J.; Finlay, M.; Conolly, J.; O’Mara, F.P. Effect of forage/concentrate ratio and dietary coconut oil level on methane output and performance of finishing beef heifers. Lives. Prod. Sci. 2003, 84, 135-146.

12. McGinn S.M.; Beauchemin K.A.; Coates T.; Colombatto D. Methane emissions from beef cattle: Effects of monensin, sunflower oil, enzymes, yeast, and fumaric acid. J. Anim. Sci. 2004, 82, $3346-3356$.

13. Külling, D.R.; Menzi, H.; Kröber, T.F.; Neftel, A.; Sutter, F.; Lischer, P.; Kreuzer, M. Methane emissions of differently fed dairy cows and corresponding methane and nitrogen emissions from their manures during storage. Environ. Monit. Assess. 2002, 79, 129-150.

14. Jarret, G.; Cozannet, P.; Martinez, J.; Dourmad, J.Y. Effect of different quality wheat dried distiller's grain solubles (DDGS) in pig diets on composition of excreta and methane production from faeces and slurry. Livest. Sci. 2011, 140, 275-282.

15. Benchaar, C.; Hassanat, F.; Gervais, R.; Chouinard, P.Y.; Julien, C.; Petit, H.V.; Massé, D.I. Effects of increasing amounts of corn dried distillers grains with solubles in dairy cow diets on methane production, ruminal fermentation, digestion, $\mathrm{N}$ balance, and milk production. J. Dairy Sci. 2013, 96, 2413-2427. 
16. Standard Methods for the Examination of Water and Wastewater, 18th ed; APHA: Washington, DC, USA, 1992.

17. van Soest, P.J.; Wine, R.H. Use of detergents in the analysis of fibrous feeds. IV. Determination of plant cell-wall constituents. Assoc. Off. Anal. Chem. J. 1967, 50, 50-59.

18. Weiss, W.P.; Willett, L.B.; St-Pierre, N.R.; Borger, D.C.; McKelvey, T.R.; Wyatt., D.J. Varying forage type, metabolizable protein concentration, and carbohydrate source affects manure excretion, manure ammonia, and nitrogen metabolism of dairy cows. J. Dairy Sci. 2009, 92, 5607-5619.

19. Hindrichsen, K.I.; Wettstein, H.R.; Machmüller, A.; Jörg, B.; Kreuzer, M. Effect of the carbohydrate composition of feed concentrates on methane emissions from dairy cows and their slurry. Environ. Monit. Assess. 2005, 107, 329-350.

20. Weiss, W.P.; Wyatt, D.J. Effect of corn silage hybrid and metabolizable protein supply on nitrogen metabolism of lactating dairy cows. J. Dairy Sci. 2006, 89, 1644-1653.

21. Møller, H.B.; Sarker, S.; Hellwin, A.L.F.; Weisbjerg, M.R. Quantification of methane production and emission from anaerobic digestion of cattle manure derived from different feeding. Available online: http://cigr.ageng2012.org/images/fotosg/tabla_137_C0327.pdf (accessed on 26 February 2014).

22. Karthikeyan, O.P.; Visvanathan, C.V. Bio-energy recovery from high-solid organic substrates by dry anaerobic bio-conversion process: A review. Rev. Environ. Sci. Biotechnol. 2013, 12, $257-284$.

(C) 2014 by the authors; licensee MDPI, Basel, Switzerland. This article is an open access article distributed under the terms and conditions of the Creative Commons Attribution license (http://creativecommons.org/licenses/by/3.0/). 